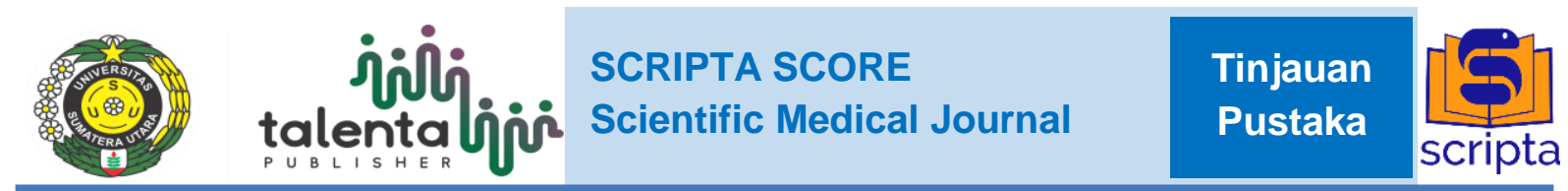

\section{Peran Reseptor IL-21 (IL-21R) sebagai Target Terapi Pada Penyakit}

\author{
Arteri Perifer \\ Muhammad Luthfi Adnan* \\ Program Studi Pendidikan Profesi Dokter, Fakultas Kedokteran, Universitas Islam Indonesia, Sleman \\ *Correspondence: luthfiadnan35@yahoo.co.id
}

\begin{abstract}
ABSTRAK
Latar Belakang: Penyakit Arteri Perifer (PAP) disebabkan karena gangguan suplai darah ke bagian perifer yang disebabkan karena sumbatan pada pembuluh darah arteri. PAP merupakan penyakit yang sulit terdeteksi dan terapi yang ada saat ini masih terbatas pada terapi farmakologis untuk menurunkan risiko kejadian PAP dan terapi pembedahan apabila timbul komplikasi PAP. Reseptor interleukin-21 (IL-21R) merupakan salah satu famili interleukin yang telah banyak dipelajari terkait perannya pada banyak penyakit. Tujuan: Tujuan dari tinjauan ini adalah untuk membahas pengaruh IL-21R terhadap perjalanan penyakit PAP. Metode: Pencarian literatur dilakukan dengan PubMed, Google Scholar, dan ScienceDirect menggunakan kata kunci "peripheral artery disease", "reseptor interleukin-21", "inflamasi", "angiogenesis", dan "terapi". Pembahasan: PAP dapat timbul karena pembentukan plak aterosklerosis yang menyumbat pembuluh darah arteri sehingga suplai darah terganggu. Pada kasus PAP, aktivasi IL-21R memiliki kemampuan untuk menstimulasi angiogenesis sehingga memodulasi perfusi jaringan yang mengalami hipoksia pada kasus PAP. Masih diperlukan penelitian lebih lanjut mengenai aktivitas IL-21R di masa depan untuk mempelajari potensi IL-21R untuk pengobatan kasus PAP yang lebih efektif di masa depan. Kesimpulan: IL-21R dapat mengaktivasi angiogenesis dan menghindari kerusakan jaringan lebih lanjut pada PAP.
\end{abstract}

Kata Kunci: penyakit arteri perifer, reseptor interleukin-21, terapi

\begin{abstract}
Background: Peripheral Artery Disease (PAD) is caused due to the disruption of blood supply to the periphery caused by blockages in the arteries. PAD is a disease that is difficult to detect and the current therapy is still limited to pharmacological therapy to reduce the risk of PAP incidence and surgical therapy if complications of PAD arise. The interleukin-21 receptor (IL-21R) is a family of interleukins that has been widely studied for its role in many diseases. Objectives: The aim of this review is to discuss the effect of IL-21R on the pathogenesis of PAP. Methods: A literature search was performed with PubMed, Google Scholar, and ScienceDirect using the keywords "peripheral artery disease", "interleukin-21 receptor", "inflammation", "angiogenesis", and "therapy". Discussion: PAD can arise due to the formation of atherosclerotic plaques that block arteries so that blood supply is impaired. In the case of PAD, activation of IL-21R has the ability to stimulate angiogenesis thereby modulating the perfusion of hypoxic tissues in cases of PAD. Further research is needed regarding IL-21R activity in the future to study the potential of IL-21R for the more effective treatment of PAD cases in the future. Conclusion: IL-21R can activate angiogenesis and avoid further tissue damage in PAP.
\end{abstract}

Keywords: interleukin-21 receptors, peripheral artery disease, therapy Received [28 Aug 2020] | Revised [9 May 2021] | Accepted [19 Aug 2021] 


\section{PENDAHULUAN}

Peripheral Artery Disease (PAD) atau penyakit arteri perifer (PAP) merupakan penyakit yang terjadi karena adanya gangguan suplai darah ke anggota tubuh bagian luar atau bagian perifer. Gangguan suplai ke perifer disebabkan adanya sumbatan pada pembuluh darah arteri yang membawa darah dari jantung ke organ tubuh. Adanya sumbatan pada pembuluh darah arteri sering disebabkan oleh terbentuknya plak aterosklerosis yang menyumbat dinding pembuluh darah. ${ }^{[1]}$ Kondisi PAP sering diikuti oleh berbagai penyakit jantung seperti infark miokard dan gagal jantung yang berisiko mengancam nyawa pasien. PAP sendiri jarang menimbulkan gejala, sehingga sulit terdeteksi oleh pasien hingga timbul gejalanya. $^{[2]}$

PAP dialami oleh lebih dari 200 juta penduduk di seluruh dunia baik pada pasien dengan PAP bergejala maupun yang tidak bergejala, yang mana pada tahun 2000-2010, angka kejadian PAD meningkat sebanyak $28,7 \%$ pada negara dengan pendapatan menengah ke bawah dan $10,69 \%$ pada negara dengan pendapatan tinggi. ${ }^{[3,4]}$ Pada beberapa studi epidemiologi, populasi pria lebih banyak memiliki PAP dibandingkan pada wanita. $^{[4]}$ Kebanyakan kasus PAP merupakan kasus asimptomatik, sehingga deteksi dini sulit dilakukan sampai timbulnya gejala. Pada pasien dengan gejala simptomatik, kasus PAD dengan gejala klaudkasio intermiten (KI) banyak terjadi pada $3 \%$ populasi berusia $>40$ tahun dan meningkatn menjadi $6 \%$ pada populasi berusia $>60$ tahun. Pada kondisi PAP yang lebih buruk, dapat timbul gejala critical limb ischemic (CLI) yang mengarah pada komplikasi lebih serius seperti amputasi dan tingkat kematian yang tinggi. Kondisi tersebut diperburuk dengan meningkatnya insidensi sindrom metabolik, diabetes, dan pola makan yang tidak seimbang yang mengakibatkan risiko peningkatan insidensi CLI. ${ }^{[5]}$
Beberapa faktor risiko yang dapat meningkatkan risiko pasien terken PAP antara lain usia tua ( $>60$ tahun), merokok, penyakit penyerta seperti hipertensi, diabetes mellitus tipe 2, dan dislipidemia. ${ }^{[6]}$ Umumnya, pasien dengan penyakit PAP tidak merasakan gejala apapun yang berkaitan dengan penyakitnya. Namun, terdapat beberapa kondisi yang dapat mengarah ke kondisi penyakit PAP. Beberapa kondisi gejala PAP antara lain yaitu nyeri pada daerah kaki atau organ perifer lain, sensasi lelah dan kram pada otot bagian bawah yang mengarah pada kondisi KI. Bila kondisi tersebut berlangsung lebih lama, akan timbul gejala yang lebih berat seperti kaki terasa kebas, kaki teraba dingin pada kaki hingga kaki terlihat menghitam karena aliran darah yang tersumbat dan berdampak pada terjadinya CLI. ${ }^{[7]}$ Dalam kondisi lebih serius, gejala tersebut dapat mengakibatkan kulit mudah terluka dan sulit sembuh karena aliran darah yang tersumbat. Akibatnya, luka yang tidak dapat sembuh akan menimbulkan infeksi dan menimbulkan komplikasi lebih serius. ${ }^{[8]}$

Terdapat beberapa terapi yang dapat dilakukan untuk menyembuhkan PAP pada pasien antara lain terapi farmakologis dan terapi pembedahan. Terapi obatobatan digunakan untuk mengurangi faktor risiko timbulnya PAP pada pasien. Obat yang dapat digunakan antara lain obat anti penggumpal darah untuk mencegah sumbatan penyebab PAP dan penurun tekanan darah. Selain itu, obat-obatan yang dapat digunakan antara lain obat penurun kadar lemak untuk mencegah sumbatan pada pembuluh darah arteri. Sedangkan terapi pembedahan merupakan pilihan utama bagi pasien PAP yang telah timbul gejala. Tujuan terapi pembedahan adalah untuk membuka sumbatan sehingga dapat menormalkan kembali aliran darah pada pembuluh darah arteri. Pilihan terapi pembedahan dilakukan bila pasien sudah tidak dapat sembuh setelah pemberian obat-obatan. Terapi pembedahan harus 
dievaluasi secara menyeluruh terhadap kondisi kaki pasien sehingga meminimalisir risiko komplikasi pasca pembedahan. ${ }^{[9]}$

Terapi yang telah ada saat ini belum dapat meningkatkan perfusi jaringan pada kondisi hipoksia yang sering timbul pada perburukan PAP. Terapi perfusi jaringan berperan penting dalam mencegah komplikasi terkait PAP. ${ }^{[10]}$ Reseptor interleukin-21 (IL-21R) merupakan salah satu famili interleukin yang telah banyak dipelajari karena perannya dalam banyak perjalanan penyakit. ${ }^{[1]}$ Beberapa studi menunjukkan peran IL-21R pada perfusi jaringan pada kondisi hipokisa yang sering timbul pada kasus PAP. ${ }^{[12]}$ Tujuan dari tinjauan ini adalah membahas proses patogenesisi PAP dan peran dari reseptor IL-21 yang memiliki potensi sebagai target terapi PAP.

\section{METODE}

Pencarian literatur menggunakan mesin pencari PubMed, Google Scholar, dan ScienceDirect dengan menggunakan kata kunci "peripheral artery disease", "reseptor interleukin-21", "inflamasi", "angiogenesis", dan "terapi". Kriteria inklusi yang digunakan adalah fulltext berbahasa Inggris dengan publikasi kurang dari 10 tahun dengan salah satu dari kombinasi kata kunci yang digunakan. Kriteri eksklusi yang digunakan adalah non- fulltext dengan publikasi lebih dari 10 tahun terakhir.

\section{PEMBAHASAN}

\section{Patogenesis Penyakit Arteri Perifer}

Kondisi PAP berhubungan dengan kejadian aterosklerosis yang ditimbulkan akibat kadar lown-density lipoprotein (LDL) dalam darah. LDL yang tinggi teragregasi oleh lapisan tunika intima arteri sehingga menstimulasi makrofag dan membentuk sel busa (foam cell) yang akan membentuk lapisan lemak yang merupakan lesi awal terbentuknya aterosklerosis. Sel otot polos vaskular kemudian akan bermigrasi dari tunika media menuju ke tunika intima pembuluh darah, menyekresikan sejumlah matriks ekstraseluler seperti kolagen sehingga meningkatkan retensi dan agregrasi lipoprotein aterogenik. Selain makrofag, sitokin proinflamasi juga terstimulus sehingga menimbulkan peradangan kronis. Proses selanjutnya berupa pembentukan fibrous cap dan inti nekrotik dari plak. Plak tersebut dapat terjadi ruptur sehingga mengalami trombus pada lumen sehingga menghalangi arteri. Kejadian terusmenerus dari rupturnya plak dapat memicu kejadian sindrom koroner akut dan infark miokardium. Pada akhirnya, jika tidak ruptur, lesi dapat terus berkembang dan mengalami obstruksi. ${ }^{[13]}$

Ateroskelrosis yang terjadi pada arteri akan berdampak pada berkurangnya perfusi pada ekstrimitas karena penyumbatan pada arteri akan mengurangi aliran darah ke bagian ekstrimitas bawah. Berkurangnya aliran darah akibat sumbatan arteri yang membawa nutrisi bagi organ ekstrimitas bawah akan mengakibatkan disfungsi vaskular. Disfungsi vaskular tersebut kemudian mengakibatkan terganggunya fungsi nitrit oksida (NO) sehingga menganggu aktivitas vasodilatasi endotel pembuluh darah. Disfungsi vaskular juga akan menganggu sirkulasi mikrovaskular yang mengakibatkan iskemik pada sel otot ekstrimitas dan disfungsi otot skeletal, yang akan berdampak pada kerusakan mitokondria sel otot. Iskemik pada sel otot akan memicu inflamasi lokal yang juga mengganggu bioaktivitas NO, yang berdampak pada perburukan fungsi vasodilatasi endotel dan menimbulkan perburukan PAP. ${ }^{[14]}$

Pada perjalanan penyakit PAP, hipoksia yang timbul akibat sumbatan pada pembuluh darah arteri akan memicu peradangan. Tahapan peradangan tersebut akan memicu pelepasan sekelompok interleukin (IL) proinflamasi seperti IL-6 dan IL-8 penanda biologis peradangan 
lainnya seperti intercelluler adhesion molecule-1 (ICAM-1) dan $C$-reactive protein (CRP) yang dapat memodulasi sel endotel, sel $\mathrm{T}$ dan makrofag. ${ }^{[15]}$ Adanya sitokin dan penanda inflamasi tersebut dapat memperburuk kondisi pasien PAP karena dapat mengganggu dilatasi vaskular yang memediasi aliran darah karena memicu stres oksidatif yang dapat menimbulkan kerusakan pembuluh darah karena menghambat produksi NO untuk dilatasi. $^{[16]}$ Karena tingkat keparahan hipoksia yang terus meningkat, adaptasi mikrovaskular kemudian tidak mampu menyuplai kebutuhan nutrisi jaringan sehingga pada kondisi lebih lanjut akan mengakibatkan jaringan yang tersumbat mengalami gangguan aktivitas penyembuhan luka dan gangren, sehingga mengakibatkan fungsi ekstrimitas terganggu. ${ }^{[17]}$

\section{Peran Reseptor IL-21 (IL-21R)}

Reseptor Interleukin-21 (IL-21R) merupakan reseptor fungsional dari IL-21, yang merupakan sitokin pleiotropik yang diproduksi dari sel natural killer (NK), sel $\mathrm{T}$ helper (Th) folikuler dan sel Th17. Reseptor fungsional IL-21 merupakan kelompok reseptor rantai $\gamma$, yang juga merupakan subunit dari reseptor sitokin IL-2, IL-4, IL-7, IL-9, dan IL-15. IL-21R telah lama dipelajari karena peran pentingnya dalam keseimbangan sistem imun, dimana pada kasus mutasi IL-21R sering terjadi pada pasien dengan imunodefisiensi. ${ }^{[18]}$ Mutasi IL-21R dapat ditemukan pada pasien dengan diare kronis, yang mana mutasi tersebut akan mempromosikan inflammataory bowel disease (IBD) yang dipicu dari pelepasan IL-21 yang berlebih. ${ }^{[19]}$ Selain itu, mutasi IL-21R akan berdampak pada berkurangnya respon sel $\mathrm{T} \mathrm{CD}^{+}$dan respon sel $\mathrm{T}$ regulator (Treg). Kondisi tersebut mengakibatkan penurunan respon imunitas humoral tubuh akibat kurangnya aktivitas sel $\mathrm{T}$, sehingga virus dapat bereplikasi dalam tubuh dan menimbulkan komplikasi terkait infeksi virus. ${ }^{[20]}$ IL-21R juga berperan penting dalam mempromosikan regulasi diferensiasi sel Th2 dan pelepasan sitokin terkait sel Th2. Aktivitas IL-21R berhubungan dengan stimulasi produksi sitokin interferon (IFN)- $\gamma$ yang dihasilkan dari diferensiasi sel Th2 menjadi sel Th1. ${ }^{[1]}$ Gangguan pada IL-21R kemudian akan berdampak pada kemampuan protektif terhadap infeksi bakteri, yang mana aktivitas protektif yang dimediasi oleh IFN- $\gamma$ yang dapat memodulasi imunitas saluran cerna. $^{[22]}$

Selain memediasi aktivitas sel T untuk meningkatkan imunitas terhadap infeksi, IL-21R juga ditemukan berperan pada aktivitas jaringan limfosit pada otak. ${ }^{[23]}$ Pada kasus stroke iskemik, ekspresi IL21R berhubungan dengan aktivitas infiltrasi limfosit ketika jaringan pembuluh darah di otak mengalami oklusi permanen. Ekspresi IL-21R akan memicu reperfusi pada jaringan yang mengalami iskemik, yang mana pada kasus stroke iskemik dapat memicu reperfusi jaringan yang mengalami infark dan memicu cedera reperfusi dan memperluas jaringan yang mengalami infark. ${ }^{[24]}$ Selain itu, pada kasus multiple sklerosis (MS), ekspresi IL21R pada jaringan yang mengalami lesi dapat memicu infiltrasi limfosit pada korteks yang mengalami MS yang berperan pada neurodegeneratsi cedera saraf dan kecacatan pada kasus MS. ${ }^{[25]}$ Meski demikian, masih sedikit peran IL21R dalam memodulasi sistem imun sehingga masih diperlukan studi lebih spesifik mengenai IL-21R terhadap pengaruhnya pada kondisi patologis. ${ }^{[26]}$

\section{Pengaruh Reseptor IL-21 (IL-21R) Pada Perbaikan Kondisi Penyakit Arteri Perifer}

Pada kondisi PAP, aktivitas IL-21R berperan pada proses perfusi melalui stimulasi angiogenesis pada jaringan yang mengalami iskemik akibat hipoksia. Aktivasi IL-21R pada sel endotel pembuluh darah dapat menstimulasi angiogenesis melalui aktivasi jalur. 
Peningkatan aktivitas jalur signal transducer and activator of transcription 3 (STAT3) akan meningkatkan gen antiapoptosis BCL-2 dan menurunkan gen pro-apoptosis BAX26. Peningkatan rasio BCL-2/BAX26 dapat menurunkan apoptosis sel dan meningkatkan kelangsungan hidup dari sel endotel. Studi yang dilakukan oleh Wang et al (2016) menunjukkan IL-21R pada sel endotel mengalami peningkatan regulasi ketika mengalami kondisi iskemik pada sel endotel. ${ }^{[27]}$ Peningkatan IL-21R dapat menstimulasi peningkatan STAT3 untuk angiogenesis melalui peningkatan ekspresi hypoxia-induced factor-1 $\alpha$ (HIF $1 \alpha)$ untuk mengaktivasi vascular endothelial growth factor (VEGF) sehingga memediasi angiogenesis untuk perfusi jaringan yang mengalami PAP. ${ }^{[28]}$

Pada studi yang dilakukan oleh Wang et al (2015), peningkatan regulasi IL-21R pada jaringan ekstrimitas bawah yang mengalami iskemik pada tikus model PAP menunjukkan adanya pemulihan perfusi jaringan melalui penghambatan maupun pencegahan apoptosis sel endotel dan mempromosikan angiogenesis melalui jalur STAT3. Pada sudi tersebut, ekspresi IL-21R bersifat adaptif, dimana pada tikus model PAP ekspresi IL-21R lebih tinggi

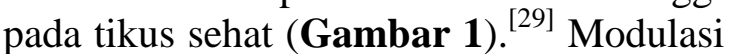
aktivitas IL-21R melalui jalur STAT3 dapat menghambat basic fibroblast-growt factor (b-FGF) untuk menginduksi proliferasi sel endotel dan menurunkan ketebalan mikrovaskular yang dapat menghambat perfusi jaringan. ${ }^{[30]}$ Aktivasi STAT3 juga menginisiasi proses remodelling vaskular melalui inisiasi migrasi sel endotel dan formasi pembentukan mikrovaskular melalui pengontrolan adesi sel lewat ekspresi molekul adesi P-selectin dan E-selectin. Peningkatan ekspresi dari molekul adesi kemudian akan memediasi angiogenesis melalui rekrutmen sitokin proinflamasi lainnya untuk mendukung angiogenesis pembuluh darah sehingga meningkatkan

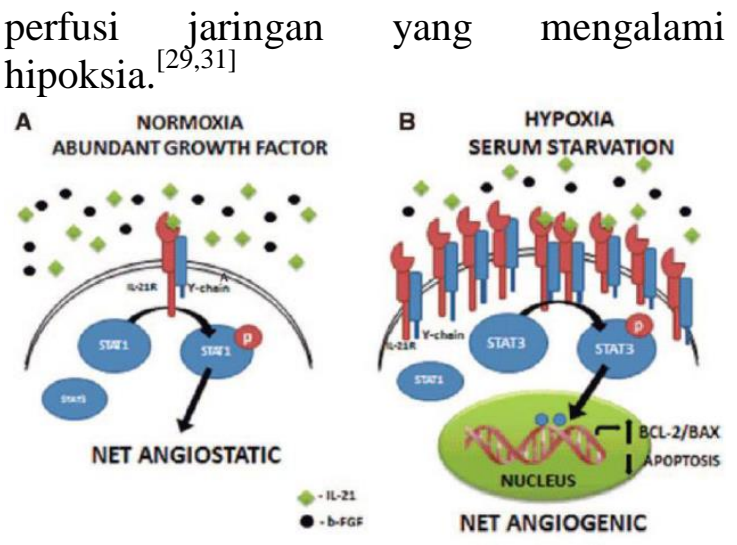

Gambar 1. Aktivitas IL-21R (A) Pada

Kondisi Normal dan (B) Pada Kondisi Hipoksia. ${ }^{[29]}$

Aktivasi jalur STAT3 juga berperan penting dalam mengekspresikan hypoxiainduced factor-1 $\alpha$ (HIF1 $\alpha)$ yang merupakan aktivator dari faktor pertumbuhan vascular endothelial growth factor (VEGF) ${ }^{[32]}$ Meski memiliki fungsi angiogenesis yang sama, mekanisme VEGF berbeda dengan IL-21R yang mengaktivasi angiogenesis melalui jalur STAT3 untuk perfusi jaringan. VEGF akan menstimulasi angiogenesis melalui jalur AKT/ERK1/2 sebagai stimulator angiogenesis untuk perfusi jaringan PAP. Meski demikian, penggunaan VEGF yang telah diujikan masih belum efektif dalam perfusi jaringan, sehingga diperlukan stimulator yang lebih poten untuk perfusi PAP. ${ }^{[29,33]}$ Melalui beberapa studi tersebut, kemampuan IL-21R dalam memodulasi perfusi jaringan yang mengalami hipoksia dapat menjadi target modulasi terapi perfusi pada kasus PAP. ${ }^{[12]}$

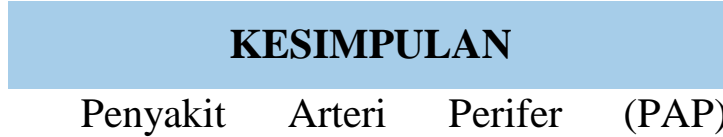
merupakan penyakit yang terjadi karena adanya gangguan suplai darah ke anggota tubuh bagian luar atau bagian perifer yang disebabkan karena sumbatan pada pembuluh darah arteri oleh terbentuknya plak aterosklerosis yang menyumbat dinding pembuluh darah. PAP merupakan penyakit yang sulit terdeteksi dan terapi yang ada saat ini masih terbatas pada terapi farmakologis untuk menurunkan 
risiko kejadian PAP dan terapi pembedahan apabila timbul komplikasi PAP. Reseptor interleukin-21 (IL-21R) merupakan salah satu famili interleukin yang telah banyak dipelajari terkait perannya pada banyak penyakit. Pada kasus PAP, aktivasi IL-21R memiliki kemampuan untuk memodulasi angiogenesis pada jaringan yang mengalami hipoksia, sehingga dapat meningkatkan perfusi jaringan pada kasus PAP. Masih diperlukan penelitian lebih lanjut mengenai aktivitas IL-21R pada subjek lainnya untuk mengetahui peran dari IL-21R sehingga dapat memaksimalkan potensi IL-21R sebagai terapi perfusi pada kasus PAP di masa depan.

\section{DAFTAR PUSTAKA}

[1] Aronow WS. Peripheral arterial disease of the lower extremities. Arch Med Sci. 2012;8(2):375-388. doi: 10.5114/aoms.2012.28568

[2] Singh SS, Pilkerton CS, Shrader CD, Frisbee SJ. Subclinical atherosclerosis, cardiovascular health, and disease risk: Is there a case for the Cardiovascular Health Index in the primary prevention population? BMC Public Health. 2018;18(1):1-11. doi:

10.1186/s12889-018-5263-6

[3] Shu J, Santulli G. Update on peripheral artery disease: Epidemiology and evidence-based facts. Atherosclerosis. 2018;275:379-381. doi: 10.1016/j.atherosclerosis.2018.05.03 $\underline{3}$

[4] Criqui MH, Aboyans V. Epidemiology of Peripheral Artery Disease. Circ Res. 2015;116(9):1509-1526. doi: 10.1161/CIRCRESAHA.116.303849

[5] Dua A, Lee CJ. Epidemiology of Peripheral Arterial Disease and Critical Limb Ischemia. Tech Vasc Interv Radiol. 2016;19(2):91-95. doi: 10.1053/j.tvir.2016.04.001

[6] Weragoda J, Seneviratne R, Weerasinghe $\mathrm{MC}$, Wijeyaratne $\mathrm{S}$. Risk factors of peripheral arterial disease: A case control study in Sri Lanka. BMC Res Notes. 2016;9(1):1-8. doi: 10.1186/s13104016-2314-x

[7] Lawall H, Huppert P, Espinola-Klein C, Rümenapf G. The diagnosis and treatment of peripheral arterial vascular disease. Dtsch Arztebl Int. 2016;113(43):729-736. doi: 10.3238/arztebl.2016.0729

[8] Hao D, Hu C, Zhang T, Feng G, Chai J, Li T. Contribution of infection and peripheral artery disease to severity of diabetic foot ulcers in Chinese patients. Int J Clin Pract. 2014;68(9):1161-1164. doi: 10.1111/ijcp.12440

[9] O’Donnell ME, Reid JA, Lau LL, Hannon RJ, Lee B. Optimal management of peripheral arterial disease for the non-specialist. Ulster Med J. 2011;80(1):33-41.

[10] Brunner G, Bismuth J, Nambi V, et al. Calf Muscle Perfusion As Measured With Magnetic Resonance Imaging To Assess Peripheral Arterial Disease. Med Biol Eng Comput. 2016;54(11):1667-1681. doi: 10.1016/j.physbeh.2017.03.040

[11] Tangye SG. Advances in IL-21 biology-enhancing our understanding of human disease. Curr Opin Immunol. 2015;34:107115. doi: 10.1016/j.coi.2015.02.010

[12] Annex BH, Beller GA. Towards the Development of Novel Therapeutics for Peripheral Artery Disease. Trans Am Clin Climatol Assoc. 2016;127:224-234.

[13] Mascarenhas J V., Albayati MA, Shearman CP, Jude EB. Peripheral arterial disease. Endocrinol Metab Clin North Am. 2014;43(1):149-166. doi: $\underline{10.1016 / \text { j.ecl.2013.09.003 }}$

[14] Hamburg NM, Creager MA. Pathophysiology of intermittent 
claudication in peripheral artery disease. Circ J. 2017;81(3):281-289. doi: 10.1253/circj.CJ-16-1286

[15] Ismaeel A, Brumberg RS, Kirk JS, et al. Oxidative stress and arterial dysfunction in peripheral artery disease. Antioxidants. 2018;7(10):116. doi: $\underline{10.3390 / \text { antiox } 7100145}$

[16] Signorelli SS, Vanella L, Abraham NG, Scuto S, Marino E, Rocic P. Pathophysiology of chronic peripheral ischemia: new perspectives. Ther Adv Chronic Dis. 2020;11:1-15. doi: 10.1177/2040622319894466

[17] Krishna SM, Moxon J V., Golledge J. A review of the pathophysiology and potential biomarkers for peripheral artery disease. Int $\mathrm{J} \mathrm{Mol}$ Sci. 2015;16(5):11294-11322. doi: 10.3390/ijms160511294

[18] Kotlarz D, Ziętara N, Milner JD, Klein C. Human IL-21 and IL-21R deficiencies: Two novel entities of primary immunodeficiency. Curr Opin Pediatr. 2014;26(6):704-712. doi:

10.1097/MOP.0000000000000160

[19] Leonard WJ, Wan CK. IL-21 Signaling in Immunity. F1000Research. 2016;5(0):1-10. doi: 10.12688/f1000research.7634.1

[20] Rasheed MAU, Latner DR, Aubert $\mathrm{RD}$, et al. Interleukin-21 Is a Critical Cytokine for the Generation of Virus-Specific Long-Lived Plasma Cells. J Virol. 2013;87(13):77377746. doi: $10.1128 /$ jvi.00063-13

[21] Wang Y, Jiang X, Zhu J, et al. IL21/IL-21R signaling suppresses intestinal inflammation induced by DSS through regulation of Th responses in lamina propria in mice. Sci Rep. 2016;6(August):1-14. doi: 10.1038/srep31881

[22] Solaymani-Mohammadi S, Berzofsky JA. Interleukin 21 collaborates with interferon- $\gamma$ for the optimal expression of interferonstimulated genes and enhances protection against enteric microbial infection. PLoS Pathog. 2019;15(2):1-27. doi: 10.1371/journal.ppat.1007614

[23] Lee HK, Keum S, Sheng H, Warner DS, Lo DC, Marchuk DA. Natural allelic variation of the IL-21 receptor modulates ischemic stroke infarct volume. $J$ Clin Invest. 2016;126(8):2827-2838. doi: 10.1172/JCI84491

[24] Clarkson BDS, Ling C, Shi Y, et al. $\mathrm{T}$ cell-derived interleukin (IL)-21 promotes brain injury following stroke in mice. $J$ Exp Med. 2014;211(4):595-604. doi: 10.1084/jem.2013137

[25] Tzartos JS, Craner MJ, Friese MA, et al. IL-21 and IL-21 receptor expression in lymphocytes and neurons in multiple sclerosis brain. Am J Pathol. 2011;178(2):794-802. doi: $\underline{10.1016 / \text { j.ajpath.2010.10.043 }}$

[26] Rankin AL, Guay H, Herber D, et al. IL-21 Receptor Is Required for the Systemic Accumulation of Activated $\mathrm{B}$ and T Lymphocytes in MRL/MpJFaslpr/lpr /J Mice. J Immunol. 2012;188(4):1656-1667. doi: 10.1038/jid.2014.371

[27] Wang T, Cunningham A, Houston $\mathrm{K}$, et al. Endothelial interleukin-21 receptor up-regulation in peripheral artery disease. Vasc Med. 2016;21(2):99-104. doi: 10.1016/j.physbeh.2017.03.040

[28] Gao P, Niu N, Wei T, et al. The roles of signal transducer and activator of transcription factor 3 in tumor angiogenesis. Oncotarget. 2017;8(40):69139-69161. doi: 10.18632/oncotarget.19932

[29] Wang T, Cunningham A, Dokun $\mathrm{AO}$, et al. Loss of Interleukin-21 Receptor Activation in Hypoxic Endothelial Cells Impairs Perfusion Recovery after Hindlimb Ischemia. Arterioscler Thromb Vasc Biol. 2015;35(5):1218-1225. doi: 10.1016/j.physbeh.2017.03.040 
[30] Akl MR, Nagpal P, Ayoub NM, et al. Molecular and clinical significance of fibroblast growth factor 2 (FGF2/bFGF) in malignancies of solid and hematological cancers for personalized therapies. Oncotarget. 2016;7(28):44735-44762. doi: 10.18632/oncotarget.8203

[31] Kim KJ, Kwon SH, Yun JH, et al. STAT3 activation in endothelial cells is important for tumor metastasis via increased cell adhesion molecule expression. Oncogene. 2017;36(39):5445-5459. doi: 10.1038/onc.2017.148

[32] Carbajo-Pescador S, Ordoñez R, Benet $\mathrm{M}$, et al. Inhibition of VEGF expression through blockade of Hifl $\alpha$ and STAT3 signalling mediates the anti-angiogenic effect of melatonin in HepG2 liver cancer cells. Br J Cancer. 2013;109(1):8391. doi: $10.1038 /$ bjc. 2013.285

[33] Iyer SR, Annex BH. Therapeutic Angiogenesis for Peripheral Artery Disease: Lessons Learned in Translational Science. JACC Basic to Transl Sci. 2017;2(5):503-512. doi: 10.1016/j.jacbts.2017.07.012 